\title{
Factors that Can Interfere with Virus Concentration from Wastewater when Using Zeta Plus 60S Filter Membranes
}

\author{
APS Queiroz ${ }^{++}$, FM Santos, CM Hársi, JMG Candeias, TA Monezi, \\ DU Mehnert ${ }^{+}$
}

\author{
Departamento de Microbiologia, Instituto de Ciências Biomédicas, Universidade de São Paulo, \\ Av. Prof. Lineu Prestes 1374, 05508-900 São Paulo, SP, Brasil
}

\begin{abstract}
Zeta plus filter membranes (ZP60S) have been shown to be efficient for rotavirus concentration from wastewater and for the reduction of cytotoxicity for cell cultures. Recently a variability in both properties was observed. In view of the low costs and the high virus recovery rates obtained in the past, we reevaluated the application of ZP60S filter membranes for virus concentration from environmental samples. Some factors that could interfere with the concentration strategy using ZP60S were also considered and assessed including the type of water to be filtered and the possible release of toxic substances from the membrane matrix during filtration.
\end{abstract}

Key words: rotavirus - cytotoxicity - positive charged membranes

The virus adsorption-elution (Viradel) technique using charged membranes, is still the most efficient method for concentration of enteric viruses from waters.

For rotavirus concentration, the use of positively charged filter membranes such as Zeta Plus (AMF Cuno) and EKS (Seitz) has been the most promissing (Sobsey \& Glass 1980, Mehnert \& Stewien 1993). Furthermore, the electropositive filter membranes efficiently remove many cytotoxic compounds and RT-PCR inhibitors from environmental samples (Hejkal et al. 1982, 1984, Queiroz 1999). Those properties are attributed to the diatomaceous-earth incorporated into the cellulose matrix of the membranes which confer the electropositive characteristic (Hejkal et al. 1982).

In Brazil, rotaviruses were detected in raw sewage and in creek water of São Paulo city by the Viradel method using Zeta Plus 60S (ZP60S) electropositive filter membranes in association with ultracentrifugation (Mehnert \& Stewien 1993). This procedure showed a mean rotavirus recovery level of $81.0 \pm 7.5 \%$ of experimentally seeded samples (Mehnert et al. 1997).

Financial support: Fundação de Amparo à Pesquisa do Estado de São Paulo, grant no. 97/3751-2

${ }^{+}$Corresponding author. Fax: +55-11-818.7354. E-mail: dumehner@icb.usp.br

++ Fapesp fellow

Received 8 November 1999

Accepted 7 April 2000
Recently, a great variability in the results, with regard to both the efficiency of virus adsorption and the elimination of cytotoxicity, was observed when using ZP60S filter membranes manufactured in 1997, practically invalidating the use of this membrane for rotavirus concentration. In view of the low costs and the high virus recovery rates obtained in the past, a re-evaluation of the application of ZP60S filter membranes for virus concentration and elimination of cytotoxicity from environmental samples was performed. Two batches of membranes, manufactured in 1997 (batches A and B), were examined with regard to those properties and the results compared to those obtained with membranes manufactured in 1988 (C).

For all assays, raw sewage and domestic sewage polluted surface water were collected at Sewage Pumping Station Edu Chaves (SPS Edu Chaves) and Pirajussara creek (São Paulo, SP), respectively, on weekdays, between 8 and 9 a.m.

The degree of fecal pollution of these samples was determined by using the kit Colilert 18 (WPO20, IDEXX, USA) to determine the most probable number (MPN) of fecal coliforms per liter. Levels of fecal coliforms were $1.2 \times 10^{8} \mathrm{MPN} /$ liter in SPS Edu Chaves water samples and $8.5 \mathrm{x}$ $10^{7}$ MPN/liter at Pirajussara creek, showing that the creek water was highly polluted. For the evaluation of the virus concentration method using both batches of ZP60S filter membranes, three pairs of 4-1 water samples were assayed as reported previously (Mehnert et al. 1997). The results shown in Table I indicate statistically significant (t Student 
test; $p=0.026$ ) differences in the recovery efficiencies using membranes $\mathrm{A}$ and $\mathrm{B}$, suggesting that the batch A was not sufficiently efficient for rotavirus concentration. On the other hand, membranes from batch B showed a virus recovery rate similar to that obtained previously when using membranes from batch C (Mehnert et al. 1997).

Based on these results, the membranes from batch $\mathrm{B}$ were used to evaluate the efficiency of rotavirus recovery from waters showing different degrees of fecal pollution (sewage and creek). The data presented in Table II demonstrates that the virus recovery rate depends upon the level of contamination of the water source. Lower virus recovery rates can be obtained from highly polluted water samples possibly due to the presence of organic and inorganic compounds that interfere with the adsorption of virus particles to the membrane (Sobsey \& Glass 1984).

To assess the efficiency of the two ZP60S batches $(\mathrm{A}$ and $\mathrm{B})$ in removing cytotoxicity from environmental water samples, $50 \mathrm{ml}$ aliquots of in natura creek water were submitted to filtration through ZP60S filter membranes with a diameter of $65 \mathrm{~mm}$. The membrane $\mathrm{C}$ was also tested using the same water samples.

Thereafter, $50 \mu$ l of filtered water sample were inoculated onto MA104 cell cultures and after 18 $\mathrm{h}$ at $37^{\circ} \mathrm{C}$ the cells were fixed with a $3 \%$ solution of formaldehyde as described previously (Mehnert \& Stewien 1993).

Different degrees of cell degeneration were observed and classified on a scale from 1+ to 4+ (Figure). The membrane manufactured in 1988 (C) efficiently removed cytotoxicity from the water samples in contrast to the batches A and B. Indeed, an increase in the level of cytotoxicity was observed in samples filtered through membranes A and B, suggesting the release of cytotoxic compounds during filtration (Table III).

To demonstrate this release of cytotoxic substances, the membranes A, B and C were wet with $10 \mathrm{ml}$ of distilled water. Subsequently, $10 \mathrm{ml}$ of Eagle's MEM were filtrated through the membranes. In a second experiment, the three batches of ZP60S membranes were rinsed with volumes of 50,100, 200 and $300 \mathrm{ml}$ of distilled water prior to filtration of the Eagle's MEM. The cytotoxicity of $50 \mu \mathrm{l}$ aliquots of all samples was assayed using MA104 cell monolayers as described previously.

TABLE I

Recovery of rotavirus SA-11 from creek water samples by the two-step concentration method, using different lots of Zeta Plus 60S (ZP60S) filter membranes

\begin{tabular}{lcrrr}
\hline & & \multicolumn{2}{c}{ Rotavirus (FFU ${ }^{a} /$ liter) } & \\
\cline { 3 - 4 } $\begin{array}{l}\text { Batches of ZP60S } \\
\text { (1997) }\end{array}$ & Trial & Virus input & Virus recovery $(\%)$ & Mean \pm SD $^{b}$ \\
\hline & 1 & $2.40 \times 10^{3}$ & $1.60 \times 10^{3}(69.5)$ & \\
A & 2 & $3.40 \times 10^{3}$ & $1.7 \times 10^{3}(50.0)$ & $60.5 \pm 9.8$ \\
& 3 & $3.40 \times 10^{3}$ & $1.8 \times 10^{3}(52.9)$ & \\
B & 1 & $2.40 \times 10^{3}$ & $2.31 \times 10^{3}(98.4)$ & \\
& 2 & $2.40 \times 10^{3}$ & $2.29 \times 10^{3}(97.4)$ & $90.7 \pm 12.4$ \\
\hline
\end{tabular}

$a:$ FFU $=$ focus forming units, as assayed by direct immunoperoxidase (DIP); $b$ : per cent \pm Standard deviation

TABLE II

Recovery of rotavirus SA-11, experimentally seeded, from sewage and creek water samples using lot B of Zeta Plus 60S filter membrane

\begin{tabular}{lcccc}
\hline & & \multicolumn{2}{c}{ Rotavirus $\left(\mathrm{FFU}^{a} /\right.$ liter $)$} & \\
\cline { 2 - 3 } Water samples & Trial & Virus input & Virus recovery $(\%)$ & Mean $\pm \mathrm{SD}^{b}$ \\
\hline \multirow{3}{*}{ Sewage } & 1 & $3.40 \times 10^{3}$ & $1.60 \times 10^{3}(47.0)$ & \\
& 2 & $3.40 \times 10^{3}$ & $2.6 \times 10^{3}(76.5)$ & $58.8 \pm 15.6$ \\
\multirow{3}{*}{ Creek } & 3 & $3.40 \times 10^{3}$ & $1.8 \times 10^{3}(52.9)$ & \\
& 1 & $2.35 \times 10^{3}$ & $2.31 \times 10^{3}(98.3)$ & \\
& 2 & $2.35 \times 10^{3}$ & $2.29 \times 10^{3}(97.4)$ & \multirow{2}{*}{$90.7 \pm 12.4$} \\
\hline
\end{tabular}

$a$ : FFU $=$ focus forming units, as assayed by direct immunoperoxidase (DIP); $b$ : per cent \pm Standard deviation 

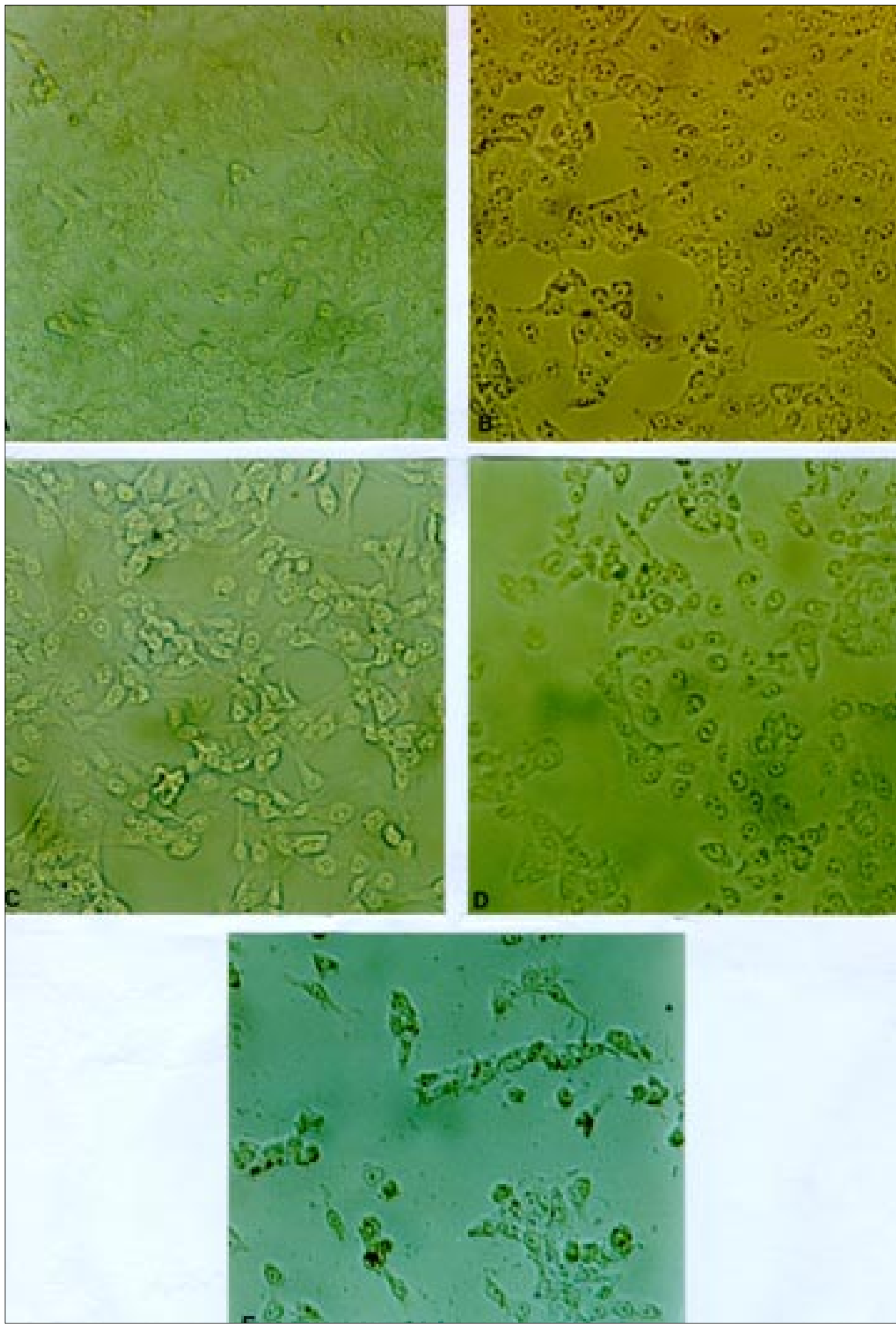

Morphological aspects of cell monolayers after inoculation of water samples: un inoculated (A) and inoculated (B-E). Magnification 200X. $1+$ approximately $10 \%$ of the cells detached from surface (B); $2+$ approximately $25 \%$ of the cells round shaped (C); 3 + aggregation in clusters, volume of the cytoplasm reduced, nuclei without visible alterations (D); $4+$ advanced cellular degeneration or total destruction $(\mathrm{E})$ 
TABLE III

Evaluation of the different batches of Zeta Plus 60S considering the property of reduction of cytotoxicity from environmental samples

\begin{tabular}{|c|c|c|c|c|c|c|}
\hline \multirow{3}{*}{$\begin{array}{l}\text { Batches of ZP60S } \\
\text { (Year of } \\
\text { manufacture) }\end{array}$} & \multirow{3}{*}{ Trial } & \multicolumn{5}{|c|}{ Results observed on MA104 cell monolayers inoculated with in natura creek water } \\
\hline & & \multirow{2}{*}{$\begin{array}{c}\text { Non- } \\
\text { filtered }\end{array}$} & \multirow{2}{*}{$\begin{array}{c}\text { Filtered } \\
\text { through } \\
\text { ZP60S }\end{array}$} & \multicolumn{3}{|c|}{ Filtered through ZP60S and diluted } \\
\hline & & & & $1 / 2$ & $1 / 4$ & $1 / 8$ \\
\hline & 1 & & $\mathrm{nd}^{a}$ & nd & nd & nd \\
\hline $\mathrm{C}$ & 2 & & nd & nd & nd & nd \\
\hline \multirow[t]{3}{*}{ (1988) } & 3 & $1+$ & nd & nd & nd & nd \\
\hline & 4 & & nd & nd & nd & nd \\
\hline & 1 & & $4+$ & nd & nd & nd \\
\hline A & 2 & & $4+$ & nd & nd & nd \\
\hline \multirow[t]{3}{*}{ (1997) } & 3 & $1+$ & $4+$ & nd & nd & nd \\
\hline & 4 & & $4+$ & nd & nd & nd \\
\hline & 1 & & $4+$ & $1+$ & $1+$ & nd \\
\hline B & 2 & & $4+$ & $1+$ & nd & nd \\
\hline \multirow[t]{2}{*}{ (1997) } & 3 & $1+$ & $4+$ & $1+$ & nd & nd \\
\hline & 4 & & $4+$ & $1+$ & nd & nd \\
\hline
\end{tabular}

$a$ : non-detectable cytopathic changes - cell monolayers showing confluence, cells without morphological changes; scores of cytotoxicity: $1+$ about $10 \%$ of the cells detached from surface; $2+$ about $25 \%$ of the cells round shaped; $3+$ aggregation in clusters, volume of the cytoplasm reduced, nuclei without visible alterations; $4+$ advanced cellular degeneration or total destruction

Both ZP60S batches, A and B, showed the release of cytotoxic substances, but this was significantly reduced by rinsing the membranes with a minimum of $300 \mathrm{ml}$ of distilled water prior to use (about $10 \mathrm{ml} / \mathrm{cm}^{2}$ ). No cytotoxicity was detected after filtration through the membrane $\mathrm{C}$ (data not shown). It is fundamental to pre-soak this type of membrane for the activation of the positive charges (Hejkal et al. 1982).

The filtration of small volumes $(10 \mathrm{ml})$ of distilled water prior the use was enough to remove an cytotoxicity in 1987-1988. However, larger volumes of distilled water must be filtrated to remove toxic substances, probably residues of diatomaceous earth, from more recent batches of membrane. This compound is a natural product extracted from various geographical locations and some minor variations in composition can occur, which may influence the efficiency of virus concentration and cytotoxicity reduction.

The dilution of filtrates can contribute to the reduction of the toxic effects on the cell cultures, but this procedure is not recommended in many cases, because enteric viruses, including rotavirus and adenovirus, are commonly present at low concentrations in environmental samples and would not be detected.

Despite some variations, the use of ZP60S seems to be recommendable for the routine concentration of viruses from environmental water samples.

\section{ACKNOWLEDGEMENTS}

To Prof. Marilis V Marques for review of the manuscript; Prof. Vivian H Pellizari and Eveline Wilma C Farias for valious assistance with coliform determinations; Cleide Rosana D Prisco for statistical analysis.

\section{REFERENCES}

Hejkal TW, Smith EM, Gerba CP 1982. Reduction of cytotoxicity in virus concentrates from environmental samples. Appl Environ Microbiol 43: 731-733.

Hejkal TW, Smith EM, Gerba CP 1984. Seasonal occurrence of rotavirus in sewage. Appl Environ Microbiol 47: 588-590.

Mehnert DU, Stewien KE 1993. Detection and distribution of rotavirus in raw sewage and creeks in São Paulo, Brazil. Appl Environ Microbiol 59: 140-143.

Mehnert DU, Stewien KE, Hársi CM, Queiroz APS, Candeias JMG, Candeias JAN 1997. Detection of rotaviruses in sewage and creek water: efficiency of the concentration method. Mem Inst Oswaldo Cruz 92: 97-100.

Queiroz APS 1999. Detecção e Genotipagem de Rotavírus Presentes em Amostras de Água de Esgoto e de Córrego da Cidade de São Paulo Através de RT$P C R$, MSc Thesis, Instituto de Ciências Biomédicas, Universidade de São Paulo, 168 pp.

Sobsey MD, Glass JS 1980. Poliovirus concentration from tap water with electropositive adsorbent filters. Appl Environ Microbiol 40: 201-210.

Sobsey MD, Glass JS 1984. Influence of water quality on enteric virus concentration by microporous filter methods. Appl Environ Microbiol 47: 956-960.

Sobsey MD, Jones BL 1979. Concentration of poliovirus from tap water using positively charged microporous filters. Appl Environ Microbiol 37: 588-595. 